\title{
PENGARUH MENONTON ACARA BERBAHASA INGGRIS, LINGKUNGAN TEMPAT TINGGAL, DAN DUKUNGAN ORANG TUA TERHADAP HASIL BELAJAR BAHASA INGGRIS SISWA
}

\author{
Varida Waty Rahayu, Bambang Sugeng \\ SMP Negeri 1 Satui Tanah Bumbu Kalimantan Selatan, Universitas Negeri Yogyakarta \\ varidawatyr@yahoo.com, -
}

\begin{abstract}
Abstrak
Penelitian ini bertujuan untuk mendeskripsikan pengaruh menonton tayangan televisi berbahasa Inggris terhadap hasil belajar siswa kelas VIII SMP/MTs di Kecamatan Satui. Penelitian ini merupakan penelitian kuantitatif dengan metode ex post facto. Populasi penelitian ini adalah seluruh siswa kelas VIII Sekolah Menengah Pertama (SMP) dan sederajat di Kecamatan Satui yang terdiri atas 671 siswa. Teknik pengambilan sampel yang digunakan adalah simple proportional random sampling. Temuan penelitian adalah sebagai berikut. (1) Terdapat pengaruh yang positif menonton tayangan televisi berbahasa Inggris terhadap hasil belajar Bahasa Inggris siswa dengan nilai $F$ regresi sebesar 17,154 dan signifikasi $0,000(p<0,05)$. (2) Terdapat pengaruh positif lingkungan tempat tinggal terhadap hasil belajar Bahasa Inggris siswa dengan nilai $F$ regresi sebesar 19,331 dan signifikansi 0,000 ( $p$ $<0,05)$. (3) Terdapat pengaruh positif dukungan orang tua terhadap hasil belajar Bahasa Inggris siswa dengan nilai $F$ regresi sebesar 24,651 dan signifikansi $0,000(p<0,05)$. (4) Terdapat pengaruh positif menonton tayangan televisi berbahasa Inggris, lingkungan tempat tinggal, dan dukungan orang tua terhadap hasil belajar Bahasa Inggris siswa secara bersama-sama dengan nilai $F$ regresi sebesar 12,606 dan signifikansi pada $0,000(\mathrm{p}<0,05)$.
\end{abstract}

Kata kunci: tayangan televisi berbahasa Inggris, lingkungan tempat tinggal, dukungan orang tua, hasil belajar

THE EFFECT OF WATCHING ENGLISH PROGRAMS, NEIGHBORHOOD, AND PARENTAL SUPPORT TOWARD ENGLISH STUDENT'S LEARNING OUTCOMES

\begin{abstract}
This research is aimed at describing the effect of watching English program toward English learning outcomes of the eighth grade students of SMP/MTs in Sub-district Satui. This research is quantitative research applied ex-post facto method. The population consisted of the eighth grade students of SMP/MTs in Sub-district Satui which consisted of 671 students. The sample was established using the proportional random sampling technique. The finding of the study shows the following. (1) There is a positive effect of watching English television programs on the students' English learning outcomes with the value of $F$ regression of 17.154 at the significance level of 0.000 $(p<0.05)$. (2) There is a positive effect of neighborhood on the students' English learning outcomes with the value of $F$ regression of 19.331 at the significance level of $0.000(p<0.05)$. (3) There is a positive effect of parental support on the students' English learning outcomes with the value of $F$ regression of 24.561 at the significance level of $0.000(p<0.05)$. (4) There is a positive effect of watching English television programs, neighborhood, and parental support on the students' English learning outcomes with the value of $F$ regression of 12.606 at the significance level of 0.000 ( $p<$ 0.05).
\end{abstract}

Keywords: English television program, neighborhood, parental support,learning outcomes. 


\section{PENDAHULUAN}

Perkembangan televisi sebagai media massa sangat pesat dari waktu ke waktu. Seiring dengan perkembangan zaman, teknologi pertelevisian semakin maju, stasiun televisi semakin banyak bermunculan dan menawarkan beragam acara atau program baik itu berupa hiburan, pendidikan, maupun informasi atau penerangan. Dalam dunia pendidikan, televisi dapat dimanfaatkan sebagai media pembelajaran yang mendukung guru dalam menyampaikan materi pelajaran sehingga proses pembelajaran menjadi lebih menarik, menyenangkan, dan lebih memberikan kesan pada ingatan anak.

Untuk dapat menerima atau menyaksikan tayangan televisi, masyarakat di Satui Kecamatan Tanah Bumbu harus menggunakan parabola ataupun televisi berlangganan. Parabola memungkinkan masyarakat untuk dapat menonton tayangan hanya dari stasiun-stasiun televisi dalam negeri, sedangkan televisi berlangganan memungkinkan masyarakat untuk menyaksikan tayangan dari stasiun televisi dalam negeri maupun stasiun televisi luar negeri. Televisi berlangganan memberikan banyak pilihan tayangan berbahasa Inggris yang dapat ditonton dalam 24 jam tanpa batas. Televisi berlangganan yang terdapat di Kecamatan Satui adalah Telkomvision, TopTV dan Indovision.

Sehubungan dengan pembelajaran Bahasa Inggris, ada banyak acara atau tayangan televisi berbahasa Inggris yang bisa ditonton dengan tujuan untuk dapat membantu meningkatkan prestasi belajar Bahasa Inggris anak. Keuntungan yang didapatkan dari menonton acara tersebut bahwa anak tidak hanya mendapatkan hiburan, informasi, tetapi juga pembelajaran yaitu dengan belajar atau berlatih Bahasa Inggris. Dalam pembelajaran Bahasa Inggris, hasil belajar siswa tidak hanya dipengaruhi oleh guru dan media pembelajaran, tetapi juga pemanfaatan sumber belajar yang terdapat di sekitar siswa secara mandiri. Salah satunya dengan pemanfaatan televisi sebagai media pembelajaran Bahasa Inggris mandiri. Dengan memanfaatkan tayangan televisi berbahasa Inggris sebagai media belajar Bahasa Inggris siswa dapat berlatih vocabulary, listening, speaking, dan pronunciation secara langsung dari acara televisi yang mereka tonton. Hasil pengamatan terbatas peneliti, diketahui bahwa sekitar 30 siswa dari 35 (sejumlah siswa dalam satu kelas) siswa kelas VIII di Kecamatan Satui menggunakan waktu mereka untuk menonton televisi.
Berdasarkan pengamatan tersebut diketahui bahwa intensitas mereka dalam menonton televisi tergolong tinggi, sehingga dapat diasumsikan bahwa tayangan yang mereka tonton memberikan kontribusi terhadap kemampuan Bahasa Inggris mereka mengingat saat ini banyak sekali tayangan televisi yang menggunakan Bahasa Inggris.

Faktor Lingkungan juga merupakan faktor yang dapat mempengaruhi hasil belajar seorang siswa. Hal ini mengingat prestasi siswa dapat berkembang dalam lingkungan yang mendukung, tetapi dapat pula terhambat dalam lingkungan yang tidak mendukung. Saat ini banyak perusahaan tambang asing yang beroperasi di Kecamatan Satui dan menyerap banyak karyawan. Kondisi ini tanpa disadari memberi pengaruh terhadap masyarakat di Satui. Kehidupan anak-anak usia sekolah membaur dengan rutinitas para pekerja tambang yang memiliki tingkat mobilitas tinggi.

Dukungan orang tua akan memberikan dampak yang positif terhadap peningkatan hasil belajar Bahasa Inggris anak. Berdasarkan pengamatan terbatas peneliti, para orang tua siswa di Kecamatan Satui memiliki kondisi sosial ekonomi yang baik sehingga dapat memberikan dukungan yang positif kepada anak-anak mereka baik secara materi maupun non-materi. Untuk mewujudkan hasil belajar Bahasa Inggris yang maksimal diperlukan dorongan dan motivasi orang tua yang berupa apresiasi, dukungan, perhatian, dan dorongan dari dalam diri siswa sendiri untuk mencapai prestasi belajar yang optimal. Di samping itu, pengawasan dan pengarahan juga harus diberikan kepada anak sehingga anak dapat tumbuh berkembang dengan baik dan terarah.

Mempertimbangkan hal-hal tersebut di atas maka peneliti mencoba untuk meneliti lebih jauh bagaimana pengaruh menonton tayangan televisi berbahasa Inggris, lingkungan tempat tinggal, dan dukungan orang tua terhadap hasil belajar Bahasa Inggris di SMP/MTs se-Kecamatan Satui, mengingat faktor-faktor tersebut sangat penting untuk dilihat dan dipertimbangkan dalam upaya peningkatan prestasi siswa, mengingat hasil belajar merupakan hasil akhir dari suatu proses belajar.

Sesuai dengan latar belakang penelitian di atas, dapat diidentifikasi sejumlah masalah yang berhubungan dengan pengaruh menonton tayangan televisi berbahasa Inggris, lingkungan tempat tinggal, dan dukungan orang tua terhadap 
hasil belajar Bahasa Inggris di Sekolah Menengah Pertama di Kecamatan Satui.

Pertama, pemanfaatan televisi sebagai media pembelajaran Bahasa Inggris di Kecamatan Satui masih tergolong kurang. Di Kecamatan Satui, televisi menjadi media hiburan utama yang ditonton oleh berbagai kalangan. Acara yang mereka minati adalah acara yang bermuatan hiburan tanpa nilai-nilai pembelajaran atau nilai pendidikan yang bermanfaat bagi peningkatan prestasi belajar anak sebagai pelajar. Sebagai contoh, orang tua menonton sinetron dalam kategori tayangan D (dewasa) yang ditayangkan pada jam belajar anak, dan anak ikut serta menonton dan mengabaikan jam belajar. Demikian halnya dengan guru-guru di sekolah, belum memanfaatkan televisi sebagai media pembelajaran Bahasa Inggris.

Kedua, lingkungan tempat tinggal siswa di Kecamatan Satui sebagian besar merupakan wilayah tambang asing. Perusahaan beroperasi selama 24 jam, sehingga mobilitas karyawan sangat tinggi. Keadaan lingkungan yang ramai oleh hiruk pikuk pekerja, dan kondisi lingkungan yang berdekatan dengan wilayah tambang dapat menyebabkan polusi udara dan suara sehingga dapat berdampak pada kesehatan, konsentrasi, dan motivasi belajar siswa.

Ketiga, kesibukan orang tua yang tinggi menyebabkan mereka kurang memberikan dukungan terhadap perkembangan belajar anak, seperti perhatian, bimbingan, serta pengawasan yang baik kepada anak. Orang tua masih berpendapat bahwa dengan memberikan dan memenuhi kebutuhan materi anak berarti memberikan dukungan yang tinggi bagi perkembangan belajar anak.

Keempat, keluhan bahwa hasil belajar Bahasa Inggris siswa masih belum optimal. Hal ini tidak berimbang dengan keinginan orang tua siswa yang mengharapkan anak-anak mereka mendapatkan nilai Bahasa Inggris yang memuaskan, dan diiringi dengan semakin meningkatnya keterampilan berbahasa Inggris mereka.

Menonton tayangan televisi berbahasa Inggris $(X 1)$, lingkungan tempat tinggal $(X 2)$, dan dukungan orang tua $(X 3)$ baik secara parsial dan secara bersama-sama, diduga akan memberi pengaruh yang positif terhadap tinggi rendahnya hasil belajar Bahasa Inggris $(Y)$ siswa.

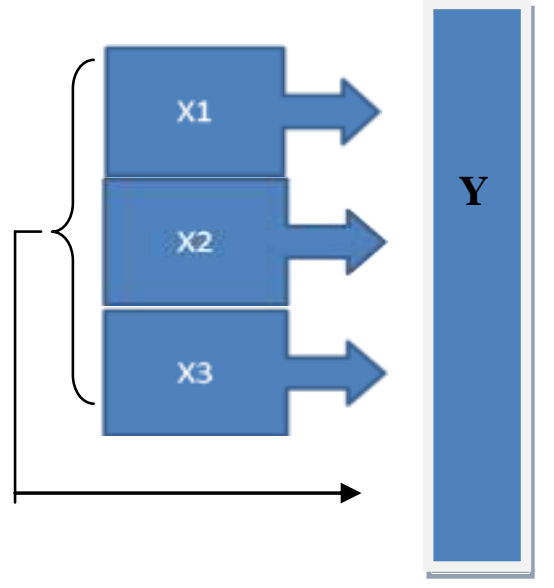

Gambar 1. Kerangka Pikir Penelitian

Dengan memperhatikan latar belakang masalah dan kajian teori yang telah dipaparkan dapat dikemukakan hipotesis penelitian sebagai berikut: (1) Terdapat pengaruh menonton acara televisi terhadap hasil belajar Bahasa Inggris; (2) Terdapat pengaruh lingkungan tempat tinggal terhadap hasil belajar Bahasa Inggris. (3) Terdapat pengaruh dukungan orang tua terhadap hasil belajar Bahasa Inggris; (4) Terdapat pengaruh menonton tayangan televisi berbahasa Inggris, lingkungan tempat tinggal, dan dukungan orang tua terhadap hasil belajar Bahasa Inggris.

\section{Metode Penelitian}

Penelitian ini merupakan penelitian kuantitatif dengan metode ex post facto. Variabel penelitian terdiri dari (1) Menonton tayangan televisi berbahasa Inggris $(X 1)$, lingkungan tempat tinggal $(X 2)$, dan dukungan orang tua $(X 3)$ sebagai variabel bebas, dan (2) Hasil belajar mata pelajaran Bahasa Inggris $(Y)$.

Penelitian dilaksanakan pada bulan Maret sampai dengan April 2012. Penelitian dilakukan di seluruh SMP/MTs di Kecamatan Satui, Kabupaten Tanah Bumbu, Provinsi Kalimantan Selatan. Di Kecamatan Satui terdapat 15 Sekolah Menengah Pertama yang terdiri atas 10 sekolah menengah negeri dan 5 sekolah menengah swasta, tetapi sekolah yang dapat dijadikan subjek penelitian hanya 14 sekolah karena satu sekolah, yaitu SMPN 9 Satui merupakan sekolah yang baru saja berdiri hanya memiliki siswa yang duduk di kelas VII saja. Sekolah-sekolah tersebut adalah: (1) SMPN I Satui,( 2) SMPN 2 Satui, (3) SMPN 3 Satui, (4) SMPN 4 Satui, (5) SMPN 5 Satui, (6) SMPN 6 Satui, (7) SMPN 7 Satui, (8) SMPN 8 Satui, (9) SMP Tanah Bumbu, (10) MTsN 1 Satui, (11) MTs Miftahussalam, (12) MTs Al Kautsar, (13) MTs Hidayatussalam, dan (14) MTs Riyadussalihin. 
Tempat penelitian ini dipilih dengan pertimbangan, bahwa Kecamatan Satui sebagai bagian dari Kabupaten Tanah Bumbu yang sedang membangun diri untuk menjadi sebuah kabupaten yang maju dan berkembang dalam segala bidang, khususnya dalam bidang pendidikan, sehingga membutuhkan masukan dari berbagai pihak menyangkut berbagai hal termasuk di antaranya penelitian yang relevan dalam dunia pendidikan.

Populasi penelitian ini adalah seluruh siswa kelas VIII Sekolah Menengah Pertama (SMP) dan sederajat di Kecamatan Satui. Pertimbangan pemilihan populasi adalah karena siswa yang duduk di kelas VIII tersebut sudah dapat mengisi angket sesuai dengan apa adanya. Berdasarkan data UPK Kecamatan Satui tahun 2011 jumlah siswa kelas VIII sekolah menengah pertama yang tercatat adalah sebanyak 671 .

Teknik pengambilan sampel yang digunakan adalah simple proportional random sampling. Kelas yang dijadikan sampel diambil pada semester genap tahun ajaran 2011/2012 dan duduk di kelas VIII sekolah menengah pertama. Langkah yang ditempuh dalam pengambilan anggota sampel adalah sebagai berikut: (a) Menentukan jumlah sampel secara proporsional. Sampel diambil dari masing-masing kelas dalam setiap sekolah secara acak berdasarkan jumlah sampel yang dibutuhkan pada setiap sekolah. Penentuan jumlah sampel dalam penelitian ini mengikuti prosedur penentuan ukuran sampel yang dikemukakan oleh Sugiyono (2010, pp.97-103). Setiap sekolah memiliki jumlah siswa yang bervariasi, dengan demikian maka masing-masing sampel untuk setiap sekolah harus proporsional sesuai dengan populasi. Penentuan jumlah sampel adalah sebagai berikut: dari jumlah populasi 671, pada tingkat kesalahan $5 \%$, maka jumlah sampel adalah 233. Setiap sekolah memiliki jumlah siswa yang bervariasi, maka masing-masing sampel untuk setiap sekolah harus ditentukan secara proporsional sesuai dengan populasi. Sampel diperoleh dari jumlah siswa kelas VIII dalam satu sekolah dibagi dengan jumlah keseluruhan populasi kemudian dikali 233:

Berdasarkan perhitungan tersebut dapat disimpulkan bahwa besarnya sampel adalah 237 orang. Dengan demikian, jumlah sampel pada setiap sekolah berbeda-beda sesuai dengan jumlah populasi siswa kelas VIII yang terdapat pada setiap sekolah.

Teknik pengambilan sampel secara random.Setelah jumlah sampel dalam setiap seko- lah telah diketahui maka sampel dipilih secara acak (random), dalam hal ini setiap siswa yang terdapat di kelas VIII memiliki peluang yang sama untuk diambil sebagai sampel.

Variabel penelitian yang dikembangkan alat ukurnya adalah menonton tayangan televisi berbahasa Inggris (X). Instrumen pengumpulan data yang pertama adalah angket. Dalam penelitian ini angket digunakan untuk memperoleh informasi tentang menonton tayangan televisi berbahasa Inggris, lingkungan tempat tinggal, dan dukungan orang tua. Angket diberikan pada seluruh siswa kelas VIII sekolah menengah pertama dan sederajat yang tersebar di seluruh Kecamatan Satui. Angket yang dipakai menggunakan skala Likert, skala tersebut digunakan untuk mengukur sikap, pendapat, dan persepsi seseorang tentang fenomena sosial (Sugiyono, 2010, p.107). Angket dikembangkan dengan nilai $4,3,2$, dan 1 . Dengan keterangan $4=$ selalu melakukan, 3 = sering, 2 = kadang-kadang, dan $1=$ tidak pernah.

Instrumen pengumpulan data yang kedua adalah wawancara. Teknik wawancara digunakan untuk mendapatkan data tambahan dan memperkuat data angket, wawancara dilakukan secara tatap muka kepada beberapa orang siswa untuk mendapatkan informasi berkaitan dengan variabel menonton tayangan televisi berbahasa Inggris. Instrumen pengumpulan data ketiga adalah dokumentasi. Dokumentasi dilakukan untuk mendapatkan data berupa dokumen tertulis yaitu nilai raport siswa yang didapat dari legger guru bidang studi Bahasa Inggris. Nilai raport tersebut adalah merupakan hasil belajar siswa dari keseluruhan kegiatan pembelajaran Bahasa Inggris yang telah diselenggarakan di sekolah menengah pertama dan sederajat di Kecamatan Satui pada bulan Desember 2011.

Untuk menguji validitas angket, digunakan korelasi product moment, untuk menguji reliabilitas angket digunakan formula koefisien alpha cronbach, dan untuk menguji normalitas data digunakan uji one-sample kolmogorov smirnov. Data hasil penelitian dianalisa dengan menggunakan analisis statistik deskriptif dan statistik inferensial. Statistik inferensial yang digunakan untuk menguji hipotesis adalah analisis regresi linear sederhana dan analisis regresi ganda. 
HASIL PENELITIAN DAN PEMBAHASAN

\section{Hasil Analisis Statistik Deskriptif}

Menonton Tayangan Televisi Berbahasa Inggris

Dari hasil analisis diperoleh hasil skor maksimum yang dicapai sebesar 110 dan skor minimum sebesar 37. Nilai mean adalah 73,22 dan standar deviasi sebesar 14,023. Dari hasil tersebut dihitung nilai rata-rata ideal $(M i)$ sebesar 73.5 yang didapat dari $(M i)=1 / 2(37+110)$, dan nilai standar deviasi ideal sebesar 12.17 yang didapat dari $(S D i)=1 / 6 \times(110-37)$.

Lingkungan Tempat Tinggal

Berdasarkan hasil perhitungan terhadap data lingkungan tempat tinggal yang berupa hasil angket sebanyak 37 butir pernyataan, diketahui bahwa nilai rata-rata yang diperoleh siswa adalah 106,11 dan standar deviasi adalah sebesar 14,839. Nilai maksimum yang diperoleh siswa adalah 142 dan nilai minimum adalah 49. Dari hasil tersebut didapat nilai rata-rata ideal $(M i)$ sebesar 95,5 yang didapat dari $(M i)=1 / 2$ $(49+142)$ dan nilai standar deviasi ideal sebesar 15.5 yang didapat dari $(S D i)=1 / 6 \times(142-49)$.

Dukungan Orang Tua

Berdasarkan hasil perhitungan terhadap data lingkungan tempat tinggal yang berupa hasil angket sebanyak 45 butir pernyataan diperoleh nilai maksimum siswa sebesar 152 dan nilai minimum sebesar 45. Rerata skor siswa adalah 110.06 dan standar deviasi adalah 18,26. Dari hasil tersebut dihitung nilai rata-rata ideal $(M i)=$ $1 / 2(45+152)$ sebesar 98,5, dan nilai standar deviasi ideal $(S D i)=1 / 6 \times(152-45)$ sebesar 17,83 .

\section{Pengujian Hipotesis}

Pengujian hipotesis dalam penelitian ini menggunakan dua analisis, yaitu analisis regresi linear sederhana yang digunakan untuk menguji hipotesis pertama, kedua, dan ketiga dan analisis regresi ganda yang digunakan untuk menguji hipotesis keempat. Setelah analisis regresi linear sederhana dan analisis regresi ganda dilakukan, peneliti menentukan garis persamaan regresi dan koefisien determinasi.

Hipotesis yang pertama dalam penelitian ini menyatakan bahwa "terdapat pengaruh antara menonton tayangan televisi berbahasa Inggris terhadap hasil belajar bahasa Inggris siswa kelas VIII SMP/MTs di Kecamatan Satui." Hasil analisis menunjukkan bahwa koefisien regresi $(F)$ antara $X 1$ terhadap $Y$ adalah 17.154 dengan signifikansi 0,000 ( $p<0,05)$. Hasil ini menunjukkan terdapat pengaruh yang positif antara menonton tayangan televisi berbahasa Inggris terhadap hasil belajar bahasa Inggris siswa kelas VIII SMP/MTs di Kecamatan Satui.

Hipotesis yang kedua dalam penelitian ini menyatakan bahwa "terdapat pengaruh antara lingkungan tempat tinggal terhadap hasil belajar Bahasa Inggris siswa kelas VIII SMP/MTs di Kecamatan Satui." Hasil analisis menunjukkan bahwa koefisien regresi $(F)$ antara $X 2$ terhadap $Y$ adalah 19,331 dengan signifikansi 0,000 ( $p<$ $0,05)$. Hasil ini menunjukkan bahwa terdapat pengaruh yang positif antara lingkungan tempat tinggal terhadap hasil belajar Bahasa Inggris siswa kelas VIII SMP/MTs di Kecamatan Satui.

Hipotesis yang ketiga dalam penelitian ini menyatakan bahwa "terdapat pengaruh antara dukungan orang tua terhadap hasil belajar Bahasa Inggris siswa kelas VIII SMP/MTs di Kecamatan Satui. Hasil analisis menunjukkan bahwa koefisien regresi $(F)$ antara $X 3$ terhadap $Y$ adalah 24,651 dengan signifikansi 0,000 $(p<0,05)$. Artinya terdapat pengaruh yang positif antara dukungan orang tua terhadap hasil belajar Bahasa Inggris siswa kelas VIII SMP/MTs di Kecamatan Satui.

Hipotesis yang keempat dalam penelitian ini adalah "terdapat pengaruh antara menonton tayangan televisi berbahasa Inggris, lingkungan tempat tinggal, dan dukungan orang tua terhadap hasil belajar Bahasa Inggris pada siswa kelas VIII SMP/MTs di Kecamatan Satui. Teknik analisis yang digunakan untuk menguji hipotesis keempat adalah analisis regresi ganda. Berdasarkan hasil pengujian diperoleh nilai $F$ sebesar 12,606. Hal ini meyakinkan bahwa terdapat pengaruh yang positif antara menonton tayangan televisi berbahasa Inggris, lingkungan tempat tinggal, dan dukungan orang tua terhadap hasil belajar bahasa Inggris pada siswa kelas VIII SMP/MTs di Kecamatan Satui.

Persamaan garis regresi dapat dinyatakan sebagai berikut: $\widehat{Y}=49,192+0,102 X 1+0,063$ $X 2+0,086 X 3$. Persamaan tersebut menunjukkan bahwa nilai koefisien $X 1$ adalah 0,102 yang berarti apabila menonton tayangan televisi bahasa Inggris $X 1$ meningkat satu angka, maka hasil belajar bahasa Inggris $(Y)$ meningkat sebesar 0,102 angka dengan asumsi $X 2$ dan $X 3$ tetap. Koefisien $X 2$ adalah 0,063 yang berarti apabila lingkungan tempat tinggal meningkat satu ang$\mathrm{ka}$, maka hasil belajar bahasa Inggris $(Y)$ meningkat adalah 0,063 angka dengan asumsi $X 1$ 
dan $X 3$ tetap. Koefisien $X 3$ sebesar 0,086 yang berarti apabila dukungan orang tua $X 3$ meningkat satu angka, maka hasil belajar bahasa Inggris $(Y)$ meningkat sebesar 0,086 angka dengan asumsi $X 1$ dan $X 2$ tetap.

Berdasarkan uji determinasi diperoleh harga koefisien determinasi $\left(R^{2}\right)$ sebesar 0,140 . Hal ini menunjukkan bahwa $14 \%$ variansi atau ragam yang terjadi pada variabel hasil belajar bahasa Inggris ditentukan oleh variabel menonton tayangan televisi berbahasa Inggris, lingkungan tempat tinggal, dan dukungan orang tua. Sementara itu, sisanya sebesar $85,7 \%$ ditentukan oleh faktor-faktor lain yang tidak dibahas dalam penelitian ini.

\section{Pembahasan}

Pengaruh Menonton Tayangan Televisi Berbahasa Inggris Terhadap Hasil Belajar

Setelah dilakukan perhitungan dengan menggunakan analisis statistik deskriptif ditemukan hasil pengujian hipotesis yang menyatakan bahwa terdapat pengaruh yang positif antara menonton tayangan televisi berbahasa Inggris terhadap hasil belajar bahasa Inggris pada siswa kelas VIII SMP/MTs di Kecamatan Satui.

Televisi memiliki manfaat yang positif, diantaranya dapat dimanfaatkan sebagai media pembelajaran. Kebiasaan menonton tayangan televisi berbahasa Inggris yang baik dan terarah dapat berpengaruh terhadap hasil belajar bahasa Inggris karena dengan menonton televisi akan menambah kosa kata baru dan mengetahui pengucapan kata atau kalimat dalam Bahasa Inggris yang benar yang diucapkan oleh penutur aslinya (native speaker). Hal tersebut sesuai dengan pendapat yang menyatakan bahwa menonton tayangan televisi berbahasa Inggris bermanfaat bagi anak antara lain dapat menambah kosa kata (vocabulary). Sumeto (2003, p.35) berpendapat bahwa dengan mendengarkan dan menonton televisi, pemirsa mendengarkan bagaimana suatu kata diucapkan dan bagaimana setiap orang yang ada dalam acara tersebut berbicara menggunakan bahasa asing yang dipelajari. Dalam mendengarkan ataupun menonton, kita belajar untuk mengerti dan memahami apa yang orang ucapkan serta meningkatkan perbendaharaan kata. Kebiasaan menonton tayangan televisi berbahasa Inggris berpengaruh terhadap hasil belajar bahasa Inggris. Dengan semakin seringnya siswa menonton tayangan televisi berbahasa Inggris maka keterampilan berbahasa mereka semakin terasah dan meningkat. Hal ini senada dengan pendapat (Halian, 2010) yang menyatakan bahwa televisi dapat menambah kosakata (vocabulary) dan memberikan wawasan sehingga anak akan mengetahui perkembangan ilmu pengetahuan dan teknologi, perkembangan peristiwa yang terjadi di dunia, dan perkembangan permasalahan yang ada di luar lingkungannya.

Hal ini diperkuat dengan hasil wawancara peneliti kepada beberapa siswa yang mendapatkan nilai Bahasa Inggris tinggi dikelas mereka dari 14 sekolah yang diteliti menjawab bahwa mereka sering menonton acara televisi berbahasa Inggris.

Menonton tayangan televisi berbahasa Inggris membantu anak memahami bagaimana budaya dari pengguna bahasa tersebut. Hal ini disebabkan karena sebagai media massa yang bersifat audiovisual, televisi memiliki fungsi sebagai media pendidikan, sebagaimana dinyatakan oleh Darwanto (2007, p.34) bahwa televisi memiliki fungsi sebagai media penerangan dan media pendidikan. Di samping itu, televisi memiliki peran yang besar dalam interaksi budaya antar bangsa karena televisi disiarkan secara serempak atau bersamaan dan mampu meliput daerah yang tidak terbatas (Darwanto, 2007, pp.43-44).

Pendapat tersebut diperkuat oleh penyataan Lyle (Darwanto, 2007, p.118) yang menyebutkan bahwa televisi merupakan jendela dunia, menonton tayangan televisi memungkinkan seseorang untuk bisa melihat dan mengembangkan daya kreasinya tentang sesuatu yang belum pernah seseorang temui, lihat ataupun alami. Televisi memberikan informasi dan ilmu pengetahuan, sehingga dengan pemahaman dan pengetahuan yang baik tentang budaya pengguna bahasa Inggris siswa akan merasa lebih mudah dalam mempelajari bahasanya.

Hal ini sesuai dengan pernyataan Darwanto (2007, p.32) yang menyebutkan bahwa televisi dapat mempengaruhi sikap, tingkah laku dan pola pikir seseorang. Siswa yang sering menonton acara televisi berbahasa Inggris belajar tentang bagaimana pengucapan dan arti suatu kata karena mereka menyaksikan dan mendengarkan secara langsung melalui acara yang mereka tonton. Sehingga dengan semakin seringnya mereka menonton acara televisi berbahasa Inggris, keterampilan berbahasa mereka menjadi semakin terasah dan meningkat. Hal ini senada dengan hasil penelitian yang dilakukan oleh Pondidi (2010), bahwa terdapat hasil yang signifikan pada siswa yang tingkat keseringannya tinggi dalam menonton film berbahasa 
Inggris, penelitian Damayanti (2010) juga menunjukkan bahwa penggunaan siaran televisi dalam pembelajaran menulis berita lebih efektif jika dibandingkan dengan menggunakan radio dan koran.

Oleh karena itu, tayangan televisi berbahasa Inggris dapat dimanfaatkan untuk meningkatkan kemampuan bahasa Inggris siswa. Dengan pengawasan yang baik dari orang tua, anak bisa memilih tayangan pendidikan dan informasi berbahasa Inggris yang sekarang semakin banyak dan beragam bentuknya. Hal tersebut bisa dilakukan agar hasil belajar bahasa Inggris mereka bisa meningkat secara simultan.

\section{Pengaruh Lingkungan Tempat Tinggal Terhadap Hasil Belajar Siswa}

Setelah dilakukan perhitungan dengan menggunakan analisis statistik didapatkan hasil pengujian hipotesis yang menyatakan bahwa terdapat pengaruh yang signifikan antara lingkungan tempat tinggal terhadap hasil belajar Bahasa Inggris pada siswa kelas VIII SMP/MTs di Kecamatan Satui.

Lingkungan tempat tinggal memberi pengaruh terhadap hasil belajar bahasa Inggris karena dengan berada di lingkungan tempat tinggal yang kondusif anak akan mendapatkan tempat yang baik untuk belajar. Hal tersebut tidak bertentangan dengan kerangka pikir penelitian yang menyatakan bahwa apabila siswa berada pada lingkungan tempat tinggal yang kondusif maka akan meningkat hasil belajar bahasa Inggris siswa. Hal ini sesuai dengan penyataan Djaali (2011, p.100) yang menyatakan bahwa keadaan lingkungan dapat membentuk kebiasaaan anak dalam belajar sehingga berpengaruh pula terhadap hasil belajarnya. Senada dengan pernyataan Djaali tersebut, Sartain (Purwanto, 2008, p.28) juga menyebutkan bahwa kondisi lingkungan dengan cara-cara tertentu dapat mempengaruhi tingkah laku, pertumbuhan, dan perkembangan manusia. Lingkungan tempat tinggal siswa di Kecamatan Satui dapat disimpulkan sebagai tempat yang baik dan memiliki suasana yang nyaman bagi siswa. Hal ini diperkuat dengan hasil wawancara peneliti kepada siswa.

Lingkungan tempat tinggal siswa memberikan sumbangan yang positif kepada siswa dalam belajar, hal ini kemudian berpengaruh kepada hasil belajar siswa. Dapat disimpulkan bahwa apabila menginginkan anaknya mendapatkan hasil belajar yang baik dan memuaskan maka orang tua harus dapat menciptakan ling- kungan tempat tinggal dengan perilaku dan kebiasaan yang baik pula agar dapat membentuk kebiasaan yang baik bagi tumbuh kembang anak. Dengan kebiasaan dan perilaku yang baik, maka anak akan termotivasi untuk mencapai prestasi belajar yang maksimal.

Hasil temuan tersebut sesuai dengan pendapat Dalyono (2010, p.60), yang menyatakan bahwa di samping orang tua, lingkungan juga merupakan faktor yang berpengaruh terhadap keberhasilan belajar siswa dalam proses pelaksanaan pendidikan. Djaali (2001, p.100) mengungkapkan bahwa lingkungan dapat membentuk kebiasaan anak dalam belajar sehingga berpengaruh pula terhadap hasil belajarnya, karena dalam pergaulan sehari-hari seorang anak akan selalu menyesuaikan diri dengan kebiasaankebiasaan lingkungannya.

Dua pendapat tersebut mengindikasikan bahwa lingkungan tempat tinggal merupakan salah satu faktor yang dapat mendukung dalam pencapaian prestasi belajar dan juga terhadap kebiasaan di mana anak itu berada. Jika anakanak yang sebaya merupakan anak-anak yang rajin belajar, maka anak akan terangsang untuk mengikuti jejak mereka.

Kondisi fisik lingkungan tempat tinggal turut mempengaruhi prestasi belajar siswa. Rumah yang rapi dengan cahaya lampu yang baik, sirkulasi udara yang sehat, sarana dan prasarana belajar yang mencukupi dan teman-teman sebaya yang berperilaku positif dan memiliki semangat belajar yang tinggi akan mendukung siswa dalam menumbuhkan motivasi berprestasi dalam diri siswa. Disamping itu, kondisi non-fisik lingkungan tempat tinggal siswa juga akan memberikan dampak terhadap prestasi belajar siswa. Mereka membutuhkan suasana yang tenang dan nyaman, hubungan yang baik antara siswa dengan antar anggota keluarga yang lain dan dengan teman sebaya. Hal ini senada pendapat dengan Djaali (2011, p.100) yang menyatakan bahwa keadaan lingkungan fisik dan lingkungan non-fisik siswa mempengaruhi pencapaian tujuan belajar siswa.

Anak-anak sebaya yang berada di sekitar seorang siswa juga mempengaruhi prestasi belajar, Dalyono (2010, p.60) menyebutkan bahwa anak-anak sebaya atau teman sebaya yang ada di tempat tinggal siswa juga bisa mempengaruhi prestasi belajar. Apabila teman-teman sebayanya adalah anak yang senang belajar dan berkeinginan untuk berprestasi disekolah dan rajin bersekolah, maka hal tersebut akan mendo- 
rong dan memotivasi anak untuk berperilaku yang sama.

Lingkungan tempat tinggal merupakan tempat anak melihat, mendengar, dan meniru apa yang mereka temukan dari lingkungan mereka. Secara alami kondisi lingkungan membantu anak memperkaya perbendaharaan kata dan mengembangkan kemampuan berbahasa mereka melalui apa yang mereka lihat, dengar, temui dari kehidupan mereka sehari-hari. Hal ini senada dengan pernyataan Djamarah (2008, p.76) yang menyatakan bahwa lingkungan juga mempengaruhi potensi berbahasa anak. Hal ini sejalan dengan apa yang ditemukan dalam penelitian ini.

\section{Pengaruh Dukungan Orang Tua Terhadap Hasil Belajar Siswa}

Setelah dilakukan perhitungan dengan menggunakan analisis statistik ditemukan hasil pengujian hipotesis yang menyatakan bahwa terdapat pengaruh yang signifikan antara dukungan orang tua terhadap hasil belajar bahasa Inggris pada siswa kelas VIII SMP/MTs di Kecamatan Satui. Orang tua adalah merupakan pendidik yang pertama dan utama bagi anakanak mereka. Pendidikan yang diberikan orang tua kepada anak sejak mereka dilahirkan merupakan pendidikan dasar dan sangat menentukan perkembangan anak selanjutnya. Untuk mencapai prestasi belajar yang memuaskan orang tua, harus diusahakan hubungan yang baik di dalam keluarga, sebagaimana yang diungkapkan oleh Nur Ahid (2010, p.63), yaitu hubungan atau relasi antara orang tua dengan anak dan relasi dengan anggota keluarga yang lain, kehidupan rumah tangga yang harmonis, tenteram, penuh kedamaian dan kasih sayang, dan suasana demokrasi. Hal ini diperkuat oleh pendapat Slameto (2010, p.62) yang menyatakan bahwa hubungan yang baik adalah hubungan yang mengandung pengertian dan kasih sayang yang disertai dengan bimbingan dan hukuman apabila dibutuhkan dalam upaya untuk mencapai keberhasilan belajar anak.

Dalam mendidik anak, orang tua sebagai orang yang memberikan pendidikan pertama kepada anak harus memberikan dasar-dasar pendidikan yang nantinya menjadi bekal bagi anak ketika mereka terjun kemasyarakat, Hal ini senada dengan pendapat Adi Tan (2009, pp.118-128) yang menyebutkan bahwa bahwa orang tua merupakan faktor paling berpengaruh terhadap perilaku sosial dan prestasi belajar anak dan status pekerjaan anak di kemudian hari. Orang tua harus mengajarkan prinsip-prinsip dasar kehidupan yang nantinya akan membentuk kepribadian anak di masa depan mereka.

Untuk memberikan dukungan yang maksimal kepada prestasi mereka di sekolah, maka orang tua harus memahami dan mengerti apa yang diinginkan dan diharapkan anak dari orang tua mereka. Hal ini sesuai hasil riset yang dilakukan oleh Galinsky (Grant \& Ray, 2010, p.81) bahwa untuk menunjang perkembangan dan prestasi sekolah anak, ada delapan hal yang harus diketahui oleh orang tua, yaitu bahwa: anak ingin merasa dianggap penting dan dicintai; anak ingin orang tua yang merespon atau menanggapi petunjuk dan isyarat dari mereka; anak ingin diterima sebagai apa adanya mereka; anak ingin orang tua yang menjunjung tinggi dan menerapkan nilai-nilai yang kuat; anak ingin disiplin yang konstruktif; anak memerlukan rutinitas dan ritual yang teratur dalam hidup mereka; anak ingin keluarga mereka ikut serta atau terlibat langsung dalam pendidikan anak; dan anak ingin orang tua mereka ada untuk mereka. Hal ini senada dengan pendapat Adi Tan (2009) yang menyebutkan bahwa bentuk tanggung jawab orang tua adalah memenuhi setiap kebutuhan anak, kebutuhan tersebut tidak hanya berbentuk makanan yang layak, memberikan hiburan dan kesenangan, ataupun pendidikan yang layak, tetapi juga harus memperhatikan kebutuhan dasar anak yang antara lain adalah: anak membutuhkan penerimaan yang tidak bersyarat artinya mereka ingin diterima apa adanya; anak membutuhkan penghargaan dan perhatian; anak membutuhkan pujian; dan anak membutuhkan disiplin yang membangun.

Orang tua yang mengerti kebutuhan anakanak mereka akan lebih memahami apa yang dibutuhkan anak agar sang anak dapat tumbuh dan berkembang dengan nilai-nilai positif dan prestasi yang bagus, dengan demikian orang tua akan dapat memposisikan diri sebagai pendukung utama anak dalam meraih prestasi di sekolah. Berdasarkan hasil wawancara peneliti kepada orang tua siswa diketahui bahwa orang tua memberikan perhatian terhadap kepentingan sekolah anak-anak mereka, mengawasi kemajuan anak, memenuhi kebutuhan anak secara materi dan non materi, dan memberikan pendidikan dasar kepada anak-anak mereka.

Cara orang tua dalam mengasuh anakanak mereka memberikan pengaruh yang sangat besar terhadap tumbuh kembang anak, karena dengan pola pengasuhan yang tepat maka anak akan terarahkan dan terdukung untuk menuju 
prestasi belajar yang maksimal. Pola pengasuhan yang diterapkan oleh orang tua haruslah pola pengasuhan yang mengarahkan anak untuk menjadi insan yang mandiri dan dapat mengandalkan diri sendiri; bertanggung jawab; memiliki jiwa sosial seperti kerja sama, bisa berbagi, dan memiliki sikap simpati kepada orang lain. Hal ini senada dengan hasil penelitian Baumrind (Santrock, 2011, p.78) yang menyebutkan bahwa orang tua yang memiliki teknik pengasuhan yang autoritatif (authoritative parenting) akan menghasilkan anak yang memiliki prestasi akademik yang baik. Orang tua yang menerapkan teknik pengasuhan autoritatif menyiapkan anak dengan tingkat keamanan emosi yang tinggi yang dapat membantu anak mereka untuk sukses di sekolah, mengedepankan komunikasi dua arah yang membantu anak untuk menumbuhkan keterampilan interpersonal yang kuat, orang tua terlibat dalam perkembangan anak dirumah maupun disekolah, dan menumbuhkan sikap mandiri dan jiwa sosial yang positif.

Selain pola pengasuhan orang tua, pendidikan orang tua dan kondisi sosial ekonomi keluarga sangat berpengaruh terhadap hasil belajar anak. Hal ini selaras dengan Sunarto dan Hartono (Djamarah,2008, p.76) yang berpendapat bahwa Jika dikaitkan dengan perkembangan kemampuan berbahasa anak, keluarga yang memiliki status sosial yang baik ataupun keluarga yang terdidik akan mampu menyediakan situasi yang baik bagi perkembangan berbahasa anak.

Dukungan orang tua memegang peranan penting untuk meningkatkan hasil belajar siswa. Hal tersebut dikarenakan anak usia SMP/MTs merupakan masa remaja di mana mereka mulai ingin mencoba berbagai hal baru. Dukungan yang baik dari orang tua baik secara material maupun bimbingan/arahan sangat diperlukan.

Dari hasil wawancara peneliti kepada orang tua siswa diketahui bahwa orang tua siswa memberikan dukungan secara material berupa penyediaan fasilitas belajar yang memadai bagi anak. Disamping itu, orang tua juga memberikan dukungan secara non-material berupa perhatian, bimbingan, dan pengawasan.

Dukungan orang tua berpengaruh terhadap hasil belajar bahasa Inggris karena dengan dukungan orang tua baik secara material berupa sarana dan prasarana belajar yang memadai maupun dukungan immaterial berupa perhatian, bimbingan dan arahan anak akan mendapatkan tempat berlindung yang aman dan nyaman dan membangkitkan motivasi untuk belajar. Motivasi dari orang terdekat yakni orang tua merupa- kan hal yang sangat dibutuhkan anak karena anak pada masa SMP/MTs masih sangat membutuhkan bimbingan dari orang tua.

\section{Pengaruh Menonton Tayangan Televisi Ber- bahasa Inggris, Lingkungan Tempat Tinggal, dan Dukungan Orang Tua Secara Bersama- Sama Terhadap Hasil Belajar Siswa}

Setelah dilakukan perhitungan dengan menggunakan analisis statistik ditemukan hasil pengujian hipotesis yang menyatakan bahwa terdapat pengaruh yang positif dan signifikan antara menonton tayangan televisi berbahasa Inggris, lingkungan tempat tinggal, dan dukungan orang tua terhadap hasil belajar bahasa Inggris pada siswa kelas VIII SMP/MTs di Kecamatan Satui.

Prestasi belajar yang memuaskan adalah harapan semua pihak, namun demikian, hasil belajar Bahasa Inggris siswa tidak dapat diraih tanpa usaha dan kerja sama yang baik antara siswa dengan faktor-faktor yang terdapat di dalam maupun di luar diri siswa. Televisi sebagai media massa yang populer di masyarakat, kondisi lingkungan tempat tinggal, dan dukungan orang tua merupakan faktor dari luar (eksternal) diri anak yang dapat berpengaruh kepada prestasi belajar anak. Tayangan televisi yang baik dan bermanfaat, lingkungan tempat tinggal yang baik dan mendukung suasana belajar bagi siswa, serta orang tua yang memberikan perhatian, bimbingan dan dukungan yang membangun diri siswa secara bersama-sama akan mendorong peningkatan terhadap hasil belajar siswa.

Dalam bidang pendidikan, televisi dimanfaatkan secara positif sebagai media pembelajaran khususnya untuk mata pelajaran Bahasa Inggris yang dapat membantu meningkatkan keterampilan berbahasa Inggris siswa. Dalam hal ini peran orang tua sangat penting dalam memilih, mengarahkan, dan mengawasi acara yang akan ditonton siswa sehingga kegiatan menonton acara televisi dapat memberi nilai positif terhadap siswa.

Hal yang tidak kalah penting lainnya adalah faktor lingkungan tempat tinggal dan dukungan orang tua. Siswa yang lingkungannya mendukung untuk belajar tentu akan lebih semangat untuk belajar sehingga hasil belajarnya meningkat. Lingkungan yang tidak kondusif dan tingkat persaingan belajar yang rendah secara otomatis akan menurunkan semangat siswa untuk belajar.

Peran orang tua terhadap pendidikan anak mereka adalah sangat penting. Untuk dapat me- 
raih hasil belajar yang baik khususnya untuk mata pelajaran Bahasa Inggris, maka orang tua harus memberikan dukungan yang kuat. Mata pelajaran Bahasa Inggris merupakan mata pelajaran yang seringkali tidak disukai oleh siswa, sehingga dalam hal ini diperlukan peran orang tua untuk dapat menumbuhkan minat anak terhadap Bahasa Inggris. Orang tua harus memberikan dukungan dan arahan tentang pentingnya belajar bahasa.

Di samping itu, orang tua juga harus menciptakan suasana belajar yang mendukung, mendampingi anak ketika sedang belajar, dan memberi fasilitas belajar yang memadai seperti buku-buku pelajaran dan buku bacaan pendukung. Dalam belajar Bahasa Inggris siswa tidak hanya dapat belajar melalui buku-buku atau guru di kelas saja tetapi juga dapat belajar melalui media lain seperti televisi. Orang tua bisa mengarahkan anak untuk belajar Bahasa Inggris melalui tayangan televisi berbahasa Inggris yang sesuai dengan usia dan perkembangan anak tetapi tidak melupakan arahan, bimbingan, dan pengawasan sehingga nilai positif dari menonton tayangan televisi dapat dirasakan.

Hal ini sesuai dengan pendapat Slameto (2010, pp.60-72) bahwa untuk meraih kesuksesan dalam belajar maka perlu diperhatikan faktorfaktor yang dapat berpengaruh kepada hasil belajar siswa. Slameto menjabarkan bahwa keluarga, lingkungan, dan media massa merupakan faktor dari luar diri siswa yang memberikan banyak pengaruh terhadap peningkatan hasil belajar siswa.

Hasil pengujian hipotesis empat memberikan gambaran bahwa secara bersama-sama kebiasaan menonton tayangan televisi berbahasa Inggris, lingkungan tempat tinggal, dan dukungan orang tua secara bersama-sama memberikan pengaruh yang lebih besar daripada setiap variabel secara sendiri-sendiri. Ada sinergi yang menjadikan nilai hasil belajar siswa lebih meningkat apabila kebiasaan menonton tayangan televisi, lingkungan tempat tinggal, dan dukungan orang tua dipadukan secara bersama-sama. Hal ini diperkuat dengan hasil wawancara peneliti bahwa terdapat peran yang saling berkaitan antara orang tua, lingkungan tempat tinggal, dan dukungan orang tua terhadap tujuan dan harapan orang tua akan tercapainya hasil belajar Bahasa Inggris yang memuaskan. Orang tua memberikan dukungan yang tinggi yang ditunjukkan dengan memberikan fasilitas dalam belajar yang cukup seperti buku-buku, komputer, televisi, ruang belajar, memberikan bimbingan, peng- awasan, dan arahan yang mendidik kepada anak. Orang tua juga memantau pergaulan sehari-hari anak, serta menyediakan lingkungan tempat tinggal yang mendukung kegiatan belajar anak. Di samping itu, ketersediaan sarana dan prasarana belajar seperti buku-buku, alat tulis, komputer, dan internet, televisi untuk mengakses tayangan televisi berbahasa Inggris, dan dengan keadaan lingkungan tempat tinggal yang teratur dan baik memberikan pengaruh yang positif terhadap hasil belajar Bahasa Inggris siswa.

\section{SIMPULAN}

Berdasarkan hasil analisis data dan pembahasan terhadap hasil penelitian, maka dapat ditarik kesimpulan sebagai berikut: (1) Terdapat pengaruh yang positif dan signifikan antara menonton tayangan televisi berbahasa Inggris terhadap hasil belajar Bahasa Inggris. Hal ini ditunjukkan dengan nilai $F$ regresi sebesar 17,154 dengan tingkat signifikansi 0,000 kurang dari 0,05 ; (2) Terdapat pengaruh yang positif dan signifikan antara lingkungan tempat tinggal terhadap hasil belajar Bahasa Inggris. Hal ini ditunjukkan dengan nilai $F$ regresi sebesar 19,331 dengan tingkat signifikansi 0,000 kurang dari tingkat signifikansi 0,05: (3) Terdapat pengaruh yang positif dan signifikan antara dukungan orang tua terhadap hasil belajar Bahasa Inggris. Hal ini ditunjukkan dengan nilai $F$ regresi sebesar 24,651 dengan tingkat signifikansi 0,000 kurang dari tingkat signifikansi 0,05 ; (4) Terdapat pengaruh yang positif dan signifikan antara menonton tayangan televisi berbahasa Inggris, lingkungan tempat tinggal, dan dukungan orang tua secara bersama-sama terhadap hasil belajar Bahasa Inggris. Nilai $F$ regresi 12,606 dengan tingkat signifikansi 0,000 kurang dari tingkat signifikansi 0,05; (5) Berdasarkan simpulan di atas dapat diketahui bahwa menonton tayangan televisi berbahasa Inggris, lingkungan tempat tinggal, dan dukungan orang tua berpengaruh terhadap hasil belajar Bahasa Inggris siswa. Maka dari itu, hal tersebut perlu mendapatkan perhatian dan tindak lanjut sebagai pengembangan agar dapat meningkatkan hasil belajar Bahasa Inggris siswa.

\section{DAFTAR PUSTAKA}

Adi Tan, Timotius. (2009). Smart parenting; parenting itu penting, kalau tidak anak menjadi genting dan sinting. Jakarta: PT. Elex Komputindo Kelompok Gramedia 
Ahid, Nur. (2010). Pendidikan keluarga dalam perspektif Islam. Yogyakarta: Pustaka Pelajar.

Dalyono. (2010). Psikologi pendidikan. Jakarta: Rineka Cipta.

Damayanti, Rini. (2010). Keefektifan penggunaan siaran televisi dan radio dalam pembelajaran keterampilan menulis berita peserta didik SMP. Tesis magister. Tidak dipublikasikan, Universitas Negeri Yogyakarta.

Darwanto. (2007). Televisi sebagai media pembelajaran. Yogyakarta: Pustaka Pelajar.

Djamarah, Saiful Bahri. (2008). Psikologi belajar. Jakarta: Rineka Cipta.

Djaali. (2011). Psikologi pendidikan. Jakarta: Bumi Aksara.

Granth, B. K. \& Ray, A. J. (2010). Home, school and community collaboration. cultury responsive family involvement. New York: Sage Production.

Halian, Aan Baidillah. (2011). Hidup anak lebih berarti dengan sehari tanpa $T V$. http://udugudug.wordpress.com/page/2/ 23. Diambil pada tanggal 23 Juli 2011.

McCharthy, M \& O'Dell, F. (2001). English vocabulary in use. Jakarta: Erlangga.
Mudjito. (2006). Pengaruh frekuensi menonton program hiburan anak-anak di televisi terhadap motivasi belajar siswa sekolah dasar negeri Mangunsari 02 Kota Salatiga. Pena wiyata. jurdik \& hum. No.05. Diambil pada tanggal 24 Juli 1011, dari http//isjd.pdii.lipi.go.id.

Munanta, Murni. (2008). Buku, mendongeng dan minat membaca. Jakarta: Kelompok Pencinta Bacaan Anak (KPBA).

Sumeto, Hudoro. (2003). Kiat menguasai bahasa asing. Jakarta. Puspa Swara.

Pondidi, Erhice. (2010). The effect of frequency of watching English movies in vocabulary mastery of students grade XI SMA Negeri I Larangan Brebes academic year 2009/2010. Tesis magister, Univeristas Ahmad Dahlan Yogyakarta.

Purwanto, Ngalim. (2010). Psikologi pendidikan. Bandung: PT. Remaja Rosdakarya.

Santrock, J. W. (2011). Educational psychology. New York: McGrawHill.

Slameto. (2010). Belajar dan faktor-faktor yang mempengaruhinya. Jakarta: Rineka Cipta. 